JAKUB BALICKI, MARTA SOBOCIŃSKA

Uniwersytet Kardynała Stefana Wyszyńskiego

$w$ Warszawie

\title{
PEDAGOGIKA PONAD GRANICAMI. WYWIAD Z PROFESOREM DIETRICHEM BENNEREM
}

J.B.: Panie Profesorze, co skłoniło Pana do wybrania pedagogiki za obszar nauki, którego zgłębianiu Pan się poświęcił?

D.B.: To pytanie jest bardzo słuszne ze względu na moją drogę kształcenia, gdyż na początku studiowałem filozofię. Gdy w Wiedniu w roku akademickim 1964-1965 obroniłem doktorat [z tej właśnie dziedziny], mój promotor Erich Heintel zaproponował mi pracę u siebie jako asystent. W tamtym czasie jednak państwo austriackie nie zezwalało na to, żeby powierzać Niemcom stanowiska naukowe w Austrii. Nie minęło jeszcze dostatecznie dużo czasu od drugiej wojny światowej. Również traktat, dzięki któremu Austria odzyskała suwerenność jako państwo neutralne, był jeszcze zbyt świeży. Dążono wówczas do wzmocnienia własnej narodowości i wobec tego musiałem wracać do Niemiec. Tam w czasie dwóch pierwszych semestrów studiowałem pedagogikę na Uniwersytecie w Bonn i w Instytucie Pedagogiki otrzymałem swoją pierwszą pracę. Co ciekawe, u austriackiego profesora Josefa Derbolava, który piastował w Bonn niemiecką profesurę.

M.S.: Co pociąga w pedagogice? 
D.B.: W odpowiedzi na to pytanie chciałbym odwołać się do dwóch doświadczeń z mojego życia osobistego, które stały się dla mnie bardzo ważne. Pierwsze $\mathrm{z}$ nich sięga okresu nauki $\mathrm{w}$ ostatnich klasach gimnazjum, w Polsce mówi się: liceum. Miałem wówczas bardzo dobrego, do dziś przeze mnie wysoko cenionego nauczyciela języka niemieckiego pana dr. Brauna. Uczestnicząc w jego zajęciach, mniej więcej dwa lata przed maturą, nieoczekiwanie spostrzegłem, że potrafię myśleć, formułować własne sądy i je zapisywać. Z pewnością spytają Państwo, co było w tym takiego pedagogicznego. Ów nauczyciel posiadał umiejętność stawiania pytań, przykładowo odnośnie do jakiegoś wiersza czy dramatu albo eseju, w taki sposób, że skłaniało to uczniów do zastanowienia się. Na jego lekcjach zauważyłem, że te pytania coś mi dają, że po zajęciach mogę dalej samodzielnie pracować nad rzeczą.

Czegoś podobnego doświadczyłem ponownie u mojego promotora w Wiedniu. Tam znowu zaobserwowałem, że dzięki nauczycielowi mogę nie tylko poznawać jakąś nową, nieznaną mi do tej pory rzecz, lecz również dyskutować o niej z innymi.

Znacznie później przeczytałem u Platona, że to, co przydarzyło mi się dwa razy w życiu, nie było wcale niczym nadzwyczajnym, lecz właśnie owym doświadczeniem, na którym zasadza się nauczanie wychowujące. W Platońskim dialogu Uczta młody ateńczyk imieniem Alkibiades chwali Sokratesa za to, że doznał u niego czegoś szczególnego, a mianowicie tego, że w jego obecności potrafi myśleć o rzeczach, których bez niego nie byłby w ogóle w stanie pojąć.

Moje spotkanie z pedagogiką było przygotowane przez dwóch nauczycieli, dzięki którym przekonałem się o możliwości nauczania w taki sposób, że uczący się jest w stanie dalej samodzielnie pracować nad rzeczą i rozmawiać o niej z innymi.

M.S.: Czy nie było jednak tak, że to właśnie filozofia utorowała Panu Profesorowi drogę do samodzielnego myślenia? 
D.B.: Filozofia bardzo mi pomogła. Ale gdy zaczynałem czytać teksty filozoficzne, początkowo w ogóle ich nie rozumiałem. Pytałem samego siebie, dlaczego zanim $\mathrm{w}$ jakimś tekście rozwinie się jakaś myśl, wszystko trwa tak długo. Dlaczego autor nie podaje odpowiedzi od razu, dlaczego stawia pytania idące najpierw w jednym kierunku, potem w innym, dlaczego zwodzi czytelnika? Przy lekturze tych tekstów potrzebowałem nauczyciela, którego pasjonuje ta swoista gra w chowanego i który wskaże mi drogę do rozumienia. Proces formułowania myśli jest tak samo ważny jak sama myśl. Również to doświadczenie było zdecydowanie pedagogiczne.

J.B.: Czy wiedza teoretyczna z zakresu pedagogiki miała wpływ - jeżeli tak, to jaki - na praktyczne wychowanie Pańskich dzieci?

D.B.: Jest to pytanie, które również często stawiała mi moja żona. Jestem przekonany, że pedagogika teoretyczna wpłynęła na moje praktyczne myślenie i działanie oraz odwrotnie. Jednak nie należy wyobrażać sobie tego w ten sposób, że od nauki dowiedziałem się, jak wychowywać. Filozofia i klasyczne teksty pedagogiczne pouczyły mnie raczej o tym, że integralną częścią własnego uczenia się myślenia i oceniania jest bycie nieustannie otwartym na irytacje i pytania pochodzące $\mathrm{z}$ doświadczenia. Odpowiednio do tego moje myślenie i działanie pedagogiczne było szczególnie dla mnie irytujące wtedy, gdy doświadczałem czegoś niespodziewanego ze strony moich dzieci i zdawałem sobie sprawę, że jest to dla mnie wyzwanie. Mogę to wyjaśnić za pomocą krótkiej historyjki o wychowaniu mojego syna Joshy.

Gdy miał dwa lata, jak tylko znalazł się wieczorem w łóżeczku, zasypiał zawsze sam. Rodzicom bardzo to odpowiadało. Ale mniej więcej około północy albo krótko potem budził się i nie chciał być sam. Przychodził więc do mnie, do pokoju, w którym pracowałem, i mówił: „Tatusiu, nie mogę spać”. Co zrobić z takim dzieckiem? Byłem poirytowany i pewnego razu odpowiedziałem: 
„Patrz, ja też nie mogę spać”. Po czym uprzątnąłem z książek jedną z półek $\mathrm{w}$ regale i tak ją urządziłem, żeby Josha mógł na niej trzymać swoje dziecięce książeczki i zabawki. I kiedy znowu przyszedł około północy do mojego pokoju, powiedziałem mu: „Ty zajmij się swoimi rzeczami, a ja swoimi”. Tak spędzaliśmy niekiedy jedną, dwie, trzy godziny - on bawiąc się, a ja pracując. Gdy się zmęczyliśmy, szliśmy spać: on do swojego łóżeczka, a ja do mojej żony.

Kiedy dzisiaj niekiedy otwieram książki, które wtedy stały w pobliżu półki służącej mojemu synowi za „skrzynkę z narzędziami”, znajduję w nich pochodzące od niego „wpisy”. Najwidoczniej używał swoich kredek do tego, żeby mnie naśladować, gdy siedziałem przy biurku, coś pisałem i czytałem; on robił tak samo, jakby umiał czytać i pisać. Wtedy w ogóle tego nie zauważyłem. Jednak Josha nie nauczył się czytania i pisania podczas nocnych wizyt w pokoju pracy ojca przez naśladowanie, lecz w szkole. Czytać i pisać nie uczymy się przez socjalizację. Potrzebujemy do tego nauczyciela, przy którym możemy doświadczyć tego, że w jego pobliżu możemy poznać coś, czego nie nauczylibyśmy się przez przyzwyczajenie ani sami, ani od innych.

M.S.: Jak to się stało, że Pan Profesor wykłada obecnie w Warszawie?

D.B.: Dla mnie samego jest to nie do końca wyjaśniona sprawa. W lecie 2008 roku niespodzianie odwiedzili mnie Dziekan wówczas jeszcze Wydziału Nauk Humanistycznych Uniwersytetu Kardynała Stefana Wyszyńskiego (UKSW) w Warszawie Pani prof. Jadwiga Kuczyńska-Kwapisz orazks. dr Dariusz Stępkowski. Ksiądz Stępkowski przygotował mnie co nieco do tej wizyty i powiedział, że być może Pani Dziekan spyta mnie o możliwość prowadzenia jakichś zajęć w Warszawie. Ale ku mojemu zdziwieniu Pani Dziekan zaproponowała mi profesurę i spytała, czy mógłbym przez 3 lata przyjeżdżać do Warszawy jako profesor. 
Powiedziałem wówczas, że odpowiedzi na to pytanie udzielę jej następnego dnia przed południem, gdy porozmawiam na temat wykładania w Warszawie z moją żoną. Nazajutrz rano przyjąłem propozycję pracy na UKSW i w ten sposób od 1 października 2008 roku jestem profesorem i kierownikiem Katedry Podstaw Pedagogiki Ogólnej. Co jednak w Warszawie doprowadziło do tego, że zwrócono się do mnie z powyższym zapytaniem, do dziś nie wiem. O szczegóły musielibyście Państwo zapytać Panią Dziekan.

J.B.: Teraz jednak, skoro jest Pan Profesor od pewnego czasu w Polsce, jak Pan ocenia poziom polskiej nauki? Jak porównałby Pan ją z niemiecką?

D.B.: Najpierw chciałbym powiedzieć kilka słów na temat Wydziału. Przybywając na nim, wyczuwam zawsze wielką solidarność między naukowcami - Paniami i Panami [res. Księżmi], także między profesorami, pracownikami dydaktycznymi i administracyjnymi. Ponieważ nie znam języka polskiego, dr Stępkowski tłumaczy mi najważniejsze rzeczy podczas posiedzeń Rady Wydziału. Ustawiam wtedy swój aparat słuchowy nieco głośniej i nikomu nie przeszkadzając, mogę słyszeć jego cichy przekład. Tą drogą wyrobiłem sobie zdanie, że gdy na Wydziale dyskutuje się o czymś, to ludzie wzajemnie się słuchają i nie ma intryg ani walki o dominację, lecz podtrzymywana przez Panią Dziekan solidarność i koncentracja na sprawie, o którą chodzi. To daje niesamowitą moc i nie jest wszędzie takie oczywiste.

Jednak są również słabości. Personel naukowy nie ma pomieszczeń do pracy, brakuje w katedrach personelu biurowego zatrudnionego na niepełnych etatach, nie ma instytucji tutora [tj. prowadzącego ćwiczenia z danej dyscypliny, który nie jest pracownikiem Uniwersytetu, np. doktorantem] ani studentów spełniających za skromnym wynagrodzeniem pewne prace pomocnicze i w końcu środki przeznaczane na badania są bardzo skromne. 
W ostatnich trzech latach, odkąd pracuję w Warszawie, pozyskałem z Deutsche Forschungs-Gemeinschaft (Niemiecka Wspólnota Badawcza) około 300000 euro na projekty, które realizuję w Berlinie. Jeden z nich dotyczy konceptualizacji instrumentu służącego do opisu i diagnozowania kompetencji moralnych u młodzieży w wieku 15 lat. Na podstawie badań pilotażowych opracowaliśmy model stopni kompetencyjnych, który będziemy teraz weryfikować w dwuletnim badaniu zasadniczym w Belinie i Brandenburgii.

$\mathrm{Na}$ początku mojej pracy w Warszawie wspólnie z dr. Stępkowskim złożyliśmy w Ministerstwie Szkolnictwa Wyższego i Nauki wniosek w sprawie zainicjowania w Polsce podobnego projektu. Opiewał on na sumę około 35000 euro na dwa lata. Chcieliśmy zatrudnić do pracy przy tym projekcie początkującą polską badaczkę i nie tyle zastosować [niemieckie] narzędzie w Polsce, ile raczej odpowiednio je przystosować w nowym otoczeniu. Nasz wniosek był w jednej recenzji chwalony w samych superlatywach, mimo to nie przyjęto go do finansowania. Prawdopodobnie wykorzystalibyśmy 50\% wszystkich środków finansowych, jakie były przewidziane dla całej Polski. Z polskiego punktu widzenia była to bezczelność, jeśli chodzi o wysokość kwoty. Ale mając do dyspozycji jeszcze mniej pieniędzy - była to zaledwie dziesiąta część sumy przyznanej w Niemczech - nie da się nawet w Polsce przeprowadzić takiego projektu.

J.B.: W obliczu różnic między Polską a Niemcami chciałbym dopytać się jeszcze o coś. Wśród młodych ludzi w Europie Zachodniej bardzo popularna stała się praktyka polegająca na tym, że przed rozpoczęciem studiów bądź już też w ich trakcie robią sobie oni roczną przerwę - gap - i poświęcają ten czas na podróżowanie po świecie, poznawanie innych kultur. W Polsce takich możliwości jeszcze nie ma. Jak Pan Profesor sądzi, skąd to się bierze, że nasi rówieśnicy przez podróże poznają świat, my zaś zaraz po ukończeniu szkoły średniej musimy studiować? 
D.B.: Gdy wzrośnie w Polsce dobrobyt, również tutaj znajdą się młodzi ludzie, którzy między maturą a studiami będą chcieli sobie wyjechać, żeby poznać świat i wypróbować to i owo. Gdy ja studiowałem, w Niemczech nie było jeszcze prawdziwego dobrobytu. Również ja podjąłem studia natychmiast po maturze. Myślę jednak, że za dziesięć lat wielu młodych Polaków będzie podróżowało po świecie.

M.S.: Czy można w jakikolwiek sposób porównać poziom kształcenia w Polsce i Niemczech? Być może wie Pan Profesor, że polski system oświatowy, włącznie ze szkołami wyższymi, od wielu lat znajduje się w fazie reform. Ci, którzy teraz rozpoczynają studia, mają zupełnie inne warunki, niż było to jeszcze nie tak dawno. Jakie różnice i podobieństwa dostrzega Pan Profesor w tym zakresie między Polską a Niemcami?

D.B.: Istnieją wyraźne różnice i istnieją również piękne podobieństwa. Zacznijmy od różnic!

W Polsce prawie całe studia polegają na wykładach. W innych krajach oprócz wykładów są jeszcze ćwiczenia, seminaria, kolokwia, tutoria itd. Bardziej zaawansowani studenci mogą sami proponować zajęcia $\mathrm{w}$ postaci tutoriów i seminariów. Wszyscy moi berlińscy doktoranci prowadzili takie zajęcia, zanim obronili doktoraty. Natomiast w Polsce wykłady odgrywają dominującą rolę. Jednak na wykładzie nie da się nauczyć samodzielnego myślenia i argumentowania. To jest chyba największa różnica, jaką dostrzegam. Ale są również bardzo piękne podobieństwa.

W ostatnim roku wspólnie z dr. Stępkowskim towarzyszyłem małej grupce osób, które zgodnie z nowym programem studiów przygotowywały prace licencjackie. Grupa liczyła zaledwie cztery studentki. Wypracowaliśmy z nimi cztery plany obejmujące praktyki pedagogiczne, część teoretyczną i badanie empiryczne. Chciałbym pokrótce zaprezentować dwie koncepcje jako przykłady. 
Pierwszy można nazwać typowo warszawskim. Mówi się w Warszawie o tzw. galeriankach. Jedna ze studentek uczyniła je tematem swojej pracy licencjackiej. Aby go rozpatrzyć, wyodrębniliśmy trzy ujęcia teoretyczne. Pierwsze stwierdza: bycie galerianką to nowa forma spędzania czasu młodości - moratorium. Młode dziewczęta nie wiążą się $\mathrm{z}$ określonym mężczyzną, lecz pozostawiają sobie otwartą przyszłość, robiąc w tym okresie zastanawiające doświadczenia. Zgodnie z drugą teorią bycie galerianką może być początkiem „kariery”, która prowadzi na okres przejściowy lub na dłuższy czas do prostytucji. Trzecia zaś hipoteza brzmiała: galerianki są fenomenem postmodernistycznym. Niewykluczone, że w rzeczywistości wcale nie istnieją. Bycie galerianką „dzieje się” tylko w internecie jako symulacja.

Jak Państwo widzicie, na początku pracy postawiliśmy trzy różne hipotezy i znaleźliśmy dla nich uzasadnienie $\mathrm{w}$ teoriach pedagogicznych i socjologicznych sięgających od Rousseau do Baudrillarda. Owa studentka pracuje ciągle nad tematem i nie skończyła jeszcze swojej pracy. $Z$ typowo polskiego tematu galerianki stały się interesującym polem badawczym dla analiz teoretycznych i empirycznych, w którym znajdują zastosowanie systematyczne pytania pedagogiczne.

Ale należałoby jeszcze zapytać, dlaczego fenomen galerianek istnieje tylko w Warszawie? Nie ma ich w Bukareszcie, Budapeszcie, Pradze, Wiedniu ani Berlinie? Myślę, że wszystkie trzy powyższe hipotezy sprawdzają się w pewnym zakresie. Da się potwierdzić hipotezę pierwszą i drugą, ale przypuszczam, że przeważającą część opisanego fenomenu należy przyporządkować do typu postmodernistycznej symulacji.

Drugi przykład jest ściśle związany ze wspomnianym powyżej przeze mnie projektem z Berlina, w którym opracowano kilkustopniową skalę służącą do ujmowania kompetencji moralnych piętnastolatków. Wskutek odrzucenia naszego wniosku dr Stępkowski i ja nie mogliśmy rozszerzyć berlińskiego projektu na Polskę. Ale w międzyczasie jedna ze studentek napisała pracę licencjacką na 
ten właśnie temat. Nie kopiowała przy tym berlińskiego projektu, lecz przygotowała własną koncepcję. W związku ze swoją pracą przebadała kompetencje moralne piętnastolatków, porównując populację młodzieży przebywającej w ośrodku wychowawczym z uczniami gimnazjum, notabene salezjańskiego. Z uzyskanych przez nią rezultatów chciałbym przedstawić tylko jeden.

Studentka ta wykazała, co było do przewidzenia, że w wielu obszarach życia młodzi ludzie uczęszczający do gimnazjum salezjańskiego wykazują wyższy poziom kompetencji moralnych [niż młodzież z ośrodka]. Ale wydobyła też na światło dzienne zaskakujący fakt, że mianowicie istnieją takie dziedziny, w których młodzież z ośrodka posiada wyższe kompetencje sądzenia i działania moralnego. Te dziedziny odnoszą się do kwestii solidarności w przyjaźni i rozróżnienia między zwyczajną kradzieżą a kradzieżą spowodowaną sytuacją bez wyjścia, np. głodem, oraz sposobów obchodzenia się ze złodziejami wśród przyjaciół. Sądzę, że to bardzo ciekawy rezultat. Wczoraj przed południem [tj. 29.06] studentka ta obroniła na wydziale swoją pracę licencjacką, otrzymując najwyższą ocenę. Była to pierwsze praca dyplomowa $\mathrm{z}$ pedagogiki ogólnej na UKSW. Jestem bardzo wdzięczny, że mogłem się do tego przyczynić.

J.B.: Działalność Pana Profesora obejmuje cały świat i zyskuje uznanie także poza granicami Niemiec. Te dwa doktoraty honoris causa, w Danii i Finlandii, dowodzą, że na wielu uniwersytetach jest znane i uznane Pańskie dzieło. Czy to Pana cieszy?

D.B.: Moja „światowa” aktywność koncentruje się na Europie i obejmuje kontakty z Chinami, Tajwanem, Japonią, USA i Kanadą. Jestem honorowym profesorem w Szanghaju. Najpiękniejszym moim doświadczeniem naukowym jest to, że mogę w gruncie rzeczy wszędzie wykładać to samo co na Uniwersytecie Humboldta w Berlinie, czy to w Szanghaju, czy w Warszawie, oczywiście przy wsparciu kolegów, którzy rozumieją rzecz i potrafią bardzo 
dobrze tłumaczyć. Widocznie we współczesnych społeczeństwach są pytania i problemy z dziedziny wychowania, które co prawda są zakorzenione w zróżnicowanych kontekstach kulturowych, ale mogą być w bardzo podobny sposób dyskutowane w Szanghaju, w Warszawie, w Berlinie, w Turku, Vasie czy Kopenhadze. Odwołam się do jednego tylko przykładu.

W Niemczech podczas moich wykładów i w pracach badawczych wiele zajmowałem się teorią wychowania. Najpierw po drugiej wojnie światowej mieliśmy fazę wychowania autorytarnego. Potem nastała faza, w której młodzież przyjęła sceptyczne nastawienie wobec dorosłych. Następnie nadeszła wielka fala emancypacji, w której postawiono pod znakiem zapytania wiele spraw związanych z wychowaniem. Po tym dała znać o sobie antypedagogika, w której mówiło się o końcu wychowania. Gdy prowadzę wykłady na ten temat przykładowo w Chinach, bardzo to interesuje chińskich studentów. Od dziesięciu, piętnastu lat kraj ten przeżywa emancypację. Na przykład dzisiaj młodzi Chińczycy sami wybierają swoich partnerów życiowych. Przed piętnastoma laty było całkiem inaczej. Gdy jakiś student zdał egzamin końcowy, prosił swojego profesora, czy mógłby mu znaleźć żonę. Pewnego razu spytałem mojego chińskiego kolegęprofesora: czy zna Pan tak wiele kobiet, że wie Pan, która będzie odpowiednia dla danego studenta? Odpowiedział mi: nie, nie. Ja nie wybieram sam, pytam moją koleżankę-profesor, czy zna jakąś studentkę, która pasuje do mojego studenta. Jeżeli przykładowo mowa jest o studencie, który jest nieco powolny, ale za to szczery, dokładny i solidny, wówczas ów profesor mówi do swojej koleżanki mniej więcej tak: znasz może jakąś studentkę, która jest troskliwa, a przy tym potrafi czasem przejąć inicjatywę? Ten mój przyjaciel, profesor z Szanghaju, jest sławny z powodu małżeństw, które skojarzył, gdyż są z zasady trwałe i było mało rozwodów. Mimo to w ostatnich dziesięciu latach coraz mniej absolwentów poszukujących żony przychodziło do niego, a dzisiaj w ogóle nikt tego nie robi. Chińską młodzież ogarnęła fala 
emancypacji. To sprawia, że bez problemów mogę podejmować na wykładach w Szanghaju tematy emancypacyjne.

Moje osobiste stanowisko w tej sprawie jest następujące: emancypacja nie jest celem wychowania. Niemniej jednak młodzi ludzie muszą się emancypować spod wpływu swoich nauczycieli. Ale ta emancypacja nie powinna być rezultatem wychowania, lecz ich własnej oryginalności i inicjatywy. Nie można zostać wychowanym do emancypacji. Można tylko emancypować siebie samego. Tak właśnie brzmiała moja krytyka niemieckiej pedagogiki emancypacyjnej w latach 60. i 70. minionego stulecia.

Także w Warszawie odważyłem się podjąć ten temat. Ale reakcja była całkowicie odmienna. W wykładach dr. Stępkowskiego i moich uczestniczą prawie wyłącznie studentki. Na moje pytanie, czy kobiety powinny się emancypować, jedna z nich udzieliła mi zdumiewającej odpowiedzi, której do tej pory nigdzie nie słyszałem. Odpowiedź ta brzmiała: o tym, czy kobieta ma się emancypować, czy nie, musi zdecydować mężczyzna. Na początku nie pojąłem, co owa studentka ma na myśli. Zrozumiałem to dopiero po dopytaniu. Owa studentka prezentowała stanowisko, które było bardzo zbliżone do mojej krytyki niemieckiej pedagogiki emancypacyjnej. Jej zdaniem celem w życiu nie jest ani emancypacja, ani nie-emancypacja. Można wyrobić w sobie formy zachowania zarówno emancypacyjne, jak i nie-emancypacyjne. To zaś, w jakim zakresie kobieta się wyemancypuje, a w jakim nie, musi uzgodnić ze swoim partnerem. Czy ta odpowiedź nie jest wspaniała?

M.S.: Od trzech lat regularnie przyjeżdża Pan Profesor do Warszawy. Z pewnością zna Pan już naszą stolicę na wylot. Może zwiedził Pan również inne polskie miasta. Jakie są Pańskie odczucia? Co myśli Pan Profesor o Polakach?

D.B.: Przed trzema laty w ogóle nie znałem Polski. Dzisiaj czuję się nieco zadomowiony w tych obszarach, z którymi mam bezpośredni kontakt. Moje kręgi to, po pierwsze, praca ze stu- 
dentami, po drugie, spotkania na wydziale, i po trzecie, życie kulturalne w Warszawie. Dariusz Stępkowski wielokrotnie wychodził ze mną na imprezy kulturalne: od polskiego folkloru aż po Międzynarodowy Konkurs Chopinowski. Czwarty krąg wiąże się z tym, że gdy jestem w Warszawie, mieszkam w klasztorze. Salezjanie podejmują mnie zawsze bardzo serdecznie i czuję się u nich prawie jak we własnym domu. Ale gdyby wywnioskowano $\mathrm{z}$ tego, że znam Polskę, to musiałbym powiedzieć, że tak nie jest. Polska jest dla mnie ciągle pełna tajemnic. Jeżeli Państwo pozwolą, chciałbym wskazać pięć ich przykładów.

Pierwsza tajemnica jest taka: nieustannie pytam siebie samego, jak Polacy mogą być tak przyjacielscy wobec niemieckiego profesora w moim wieku po wszystkich tych okrucieństwach, zbrodniach i przestępstwach, jakich dopuścili się w Polsce Niemcy podczas drugiej wojny światowej? Drugą tajemnicę stanowi dla mnie polska historia. Zapytuję siebie samego, dlaczego Niemcy tak niewiele wiedzą o polskiej historii? Dopiero tutaj dowiedziałem się, że Polacy są wielkim europejskim narodem o wielowiekowych dziejach i że polski król obronił Europę przed Turkami pod Wiedniem.

Jest jeszcze czwarty punkt tego mojego rozumienia i nierozumienia. Ogromne wrażenie zrobiło na mnie to, jak Polacy opłakiwali śmierć prezydenta Kaczyńskiego i innych polskich przedstawicieli, między nimi również Rektora UKSW. Uczestniczyłem osobiście w tym smutku. Ale potem nie mogłem pojąć, jak podczas żałoby można było się kłócić o to, czy wolno pochować Prezydenta na Wawelu. Nie tak dawno odwiedziłem Kraków i byłem na Wawelu. Prezydent Kaczyński w ogóle nie spoczywa w krypcie razem z polskimi królami. Złożono go poza obszarem wydzielonym dla królów, oddzielnie, u boku Józefa Piłsudskiego, który ogromnie się zasłużył dla Polski. Poza tym przez pamiątkową tablicę została tam uczczona pamięć nie tylko Prezydenta, lecz również wszystkich ofiar tragedii w Smoleńsku. Żałoba i ten spór utrudniają mi zrozumienie polskiego narodu. Jak można równocześnie być pogrążonym w żałobie i tak się spierać? Może to 
polskie zespolenie żałoby i kłótni jest jakąś nową demokratyczną cnotą? Nie wiem.

Istnieje jeszcze inna tajemnica. Gdy przybywa się z Niemiec i co nieco poznało stosunki wschodnioniemieckie, nieodparcie nasuwa się spostrzeżenie, że Polska mimo socjalizmu pozostała krajem katolickim. Jednak dzisiaj również tutaj dokonuje się proces sekularyzacji, w którym nagle się okazuje, że prawo, religia, sztuka, nauka i polityka kierują się zupełnie odmiennymi logikami myślenia i działania. Patrząc od tej strony, Polska jest dla mnie miejscem modernizacji całkowicie nowego rodzaju. Ta modernizacja nie powoduje zaniku religii, lecz jej przekształcenie.

$\mathrm{Z}$ niemieckiego punktu widzenia pytam się czasami, co Polska ze swojego doświadczenia rozbiorów może wnieść do historii europejskiej. Polska jest dla mnie krajem, który tak często był dzielony i anektowany przez Austrię, Rosję. A zatem jest to kraj, w którym troska o własną jedność jest bardzo żywa i musi stać się dzisiaj troską o jedność nie tylko narodową, lecz również europejską. Ale czy w dzisiejszej Polsce żywi się jeszcze obawę przed nowym podziałem kraju? Wyobraźmy sobie, że nad brzegiem Morza Bałtyckiego zostałaby zbudowana elektrownia atomowa i że zdarzyłoby się to samo, co na Ukrainie i w Japonii! Polska uległaby podziałowi na wiele tysięcy lat, stałaby się krajem bez zamieszkałego wybrzeża morskiego.

J.B.: Panie Profesorze, chciałbym teraz zapytać o Pańską koncepcję pedagogiki ogólnej. Czy istnieje jakiś wspólny mianownik między doświadczeniem, wiedzą, nauką i pedagogiką?

D.B.: Takiego wspólnego mianownika między doświadczeniem, wiedzą, nauką i pedagogiką można by się doszukiwać w tym, że w wymienionych czterech obszarach ogromne znaczenie mają negatywne doświadczenia. Co prawda zazwyczaj przypisuje się większą rolę pozytywnym doświadczeniom niż negatywnym, ale te ostatnie są przynajmniej tak samo ważne. Zanim dziecko 
po raz pierwszy dosięgnie swoimi rączkami tego, co widzi i chce chwycić, musi pokonać wiele negatywnych doświadczeń związanych z brakiem koordynacji zmysłu dotyku i wzroku, wskutek czego niejednokrotnie poniosło porażkę. Może więc w zdolności do uczenia się z negatywnych doświadczeń spoczywa jakiś wspólny mianownik pedagogiki, doświadczenia, wiedzy i nauki.

W mojej Pedagogice ogólnej rozróżniłem cztery podstawowe pojęcia pedagogiczne, które są istotne ze względu na interpretację negatywnych i pozytywnych doświadczeń. Pierwsze z tych pojęć orzeka: każdy człowiek jest ukształcalny, tzn. gromadzi negatywne doświadczenia i uczy się na ich podstawie. W drugim pojęciu twierdzi się: aby to uczenie się było możliwe, dzieci muszą być wzywane do własnej aktywności. Trzecie pojęcie stanowi: żeby dzieci w naszym społeczeństwie mogły w ogóle uczyć się przez wykonywanie zadań, konieczne jest przetransformowanie owych zadań na takie, które będę odpowiadały ich możliwościom. I w końcu w czwartym pojęciu podstawowym mówi się: proces wychowania jest tak samo ważny jak jego efekt. Wychowanie nie jest tylko środkiem do osiągnięcia jakiegoś celu, lecz jest drogą, która ma konstytutywne znaczenie dla samego celu. W tym świetle wychowanie moralne jest tak samo ważne jak kształcenie i rozwój moralności. Nie można powiedzieć, że moralność jest ważniejsza niż wychowanie moralne. Również odwrotne założenie byłoby fałszywe. Poza tym pozostaje prawdziwy pogląd, że moralność i wychowanie moralne nie są ważniejsze od religii, nauki, polityki czy ekonomii. Wszystkie te sfery nie znajdują się wobec siebie w układzie hierarchicznym, lecz niehierarchicznym.

Gdyby rozwinąc tę sprawę jeszcze nieco dalej, to można by wówczas dotrzeć do zaskakującego wniosku, który odnosi się do zadań publicznego systemu oświaty. W różnych rodzajach ustrojów próbowano zaanektować wychowanie na służbę ideologii danego ustroju. Państwom demokratycznym nie wolno tego robić. Spraw, wokół których toczy się w nowoczesnym społeczeństwie spór $\mathrm{w}$ polityce, ekonomii, religii, kulturze i nauce, nie wolno 
rozstrzygać za pomocą wychowania. To ostatnie ma wprowadzać dorastające pokolenie w ów spór, ale nie jest uprawnione do tego, żeby go rozwiązywać. Jeżeli dzieje się inaczej, to wówczas wychowawcy i nauczyciele przejmują w państwie rolę polityków. To jednak nie może mieć miejsca w demokracji, dla której kształtowanie woli politycznej jest zadaniem priorytetowym tak w odniesieniu do poszczególnych jednostek, jak i całego narodu.

M.S.: Czy mógłby Pan Profesor zająć stanowisko wobec szeroko w Polsce rozpowszechnionej idei tzw. wychowania bezstresowego?

D.B.: Wychowanie bez stresu to wyobrażenie starej skądinąd pedagogiki reformy. Ale musimy rozróżnić stres pozytywny i stres negatywny. Ten ostatni czyni człowieka zmęczonym, nieaktywnym, pod jego wpływem nie można się uczyć. Natomiast pozytywny stres stawia wyzwania, konfrontuje z czymś nieznanym. Powiedziałbym tak: wychowanie musi wzywać do uczenia się, musi stawiać trudne pytania, żądać wysiłku od uczących się i przede wszystkim musi przepracowywać błędy, pomyłki, problemy i pytania oraz kultywować właściwe obchodzenie się z pedagogicznymi trudnościami, a niekiedy nawet przyznać się do niepowodzenia. Przez negatywne doświadczenie polegające na tym, że nie umiem rozwiązać zadania z matematyki, może zrodzić się we mnie zainteresowanie nią. To znaczy: w wychowaniu musimy unikać negatywnego stresu, który odbiera ochotę do pracy, ale dopuścić błędy, pomyłki, problemy i pytania oraz to, jak je przepracowywać. Nie obejdzie się tutaj bez pozytywnego stresu spowodowanego negatywnymi doświadczeniami. Ale wolałbym nie używać słowa „stres”, lecz raczej „wysiłek”.

J.B.: Skąd w naszym społeczeństwie biorą się, zdaniem Pana Profesora, problemy wychowawcze? Czy wychowanie dzisiaj stało się trudniejsze niż w innych epokach? 
D.B.: Od czasów Sokratesa zwykło się mówić, że młodzież jest coraz gorsza, a wychowanie trudniejsze. Skąd biorą się problemy wychowawcze? Trudności powstają zawsze na styku struktur, w których spotyka się logika myślenia pedagogicznego i pozapedagogicznego. Gdyby nie było trudności wychowawczych, nie byłoby również problemów pedagogicznych związanych z rozwojem ani postępu. Trzeba przyjrzeć się z obu stron owym sferom nakładania się na siebie obszarów pedagogicznych i niepedagogicznych oraz je prześledzić. Chciałbym wskazać trzy takie dziedziny.

Pierwsza z nich dotyczy tego, że musimy stosować wobec dzieci dozór i przymus, a mimo to trzeba stawiać sobie równocześnie pytanie, kiedy i w jakim zakresie są one dozwolone. Jedna z odpowiedzi na to pytanie brzmi: przymus trzeba stosować wobec dzieci wszędzie tam, gdzie w przeciwnym przypadku wyrządziłyby sobie jakąś krzywdę albo nawet uśmierciły. Trzeba zatem autorytarnie zatroszczyć się o to, żeby przykładowo dziecko nie utonęło w morzu, nie wypadło przez okno, nie pchało nożyczek do gniazdka z prądem, nie poparzyło się wrzątkiem. Jednak musimy w taki sposób aranżować te sytuacje wychowawcze, żeby nie wymagały od nas ciągłego wywierania przymusu. Dlatego urządzamy środowisko przebywania dzieci tak, by ograniczać zagrożenia i uczynić je kontrolowalnymi.

Drugą dziedziną jest nauczanie szkolne. Ta forma uczenia się jest konieczna, gdyż dzięki niej dzieci poznają rzeczy potrzebne do życia, których nie nauczyłyby się wprost przez samo życie. Lekcja jest sztucznym sposobem nauczania, gdyż nie uczymy się na niej bezpośrednio przez doświadczenie. Ten sztuczny charakter trzeba jednak uczynić interesującym, żeby czytanie i pisanie, rachunki i rysowanie, historia i języki obce, wiedza przyrodnicza i technika oraz wiele innych przedmiotów skłaniały do pytań i były zrozumiałe.

Trzecia dziedzina działania pedagogicznego i związanych z nim trudności to troska o to, żeby otworzyć przed pokoleniem 
dorastających wystarczające możliwości uczestnictwa w życiu społecznym i żeby istniały odpowiednie płaszczyzny przejścia z sytuacji pedagogicznych do pozapedagogicznych, to znaczy realnego życia. To są według mnie trzy pola pedagogiczne, w których współczesne społeczeństwa muszą poszukiwać rozwiązań trudności wychowawczych.

M.S.: Co zdaniem Pana Profesora jest najważniejsze w życiu?

D.B.: Nie wiem. Nie wiem, czy w ogóle jest coś, co można by nazwać najważniejszym w życiu. W różnych fazach naszego życia poznajemy różne formy ważności. Na pewno na początku jest ważne, żeby dziecko miało rodziców lub osoby, z którymi nawiąże bliskie relacje, które będą się o nie troszczyć. Potem potrzebuje ono dobrych nauczycieli. Potem musi nauczyć się zawodu. W końcu ludzie szukają partnerów, którzy będą pasować do nich. To wspaniałe, gdy można całą drogę życia przejść z jedną osobą, dzielić z nią różne jego okresy. Powstaje wówczas coś takiego jak świadomie przepołowiona historia życia. Ale biorąc pod uwagę wszystkie te postacie ważności, nie ma w życiu samych tylko sukcesów, są niepowodzenia, negatywne doświadczenia, które muszą zostać „przetrawione”. Co w tym wszystkim jest najważniejsze? Naprawdę nie wiem.

Ale może mógłbym wymienić pięć, sześć punktów. Do dobrego życia należy interesowanie się polityką i uczestniczenie w dyskusjach na ten temat. Dalej, do dobrego życia należy uczestnictwo w doskonaleniu obyczajów i moralności oraz w toczących się na jej temat debatach. Do dobrego życia należy też nie tylko bycie wychowanym, ale również wychowywanie innych i wzięcie na siebie części odpowiedzialności za te sprawy. W końcu do dobrego życia należy nie bycie utrzymywanym przez innych, lecz samodzielne zaspokajanie swoich potrzeb przez własną pracę. $\mathrm{Z}$ bezrobotnymi nie można budować demokracji. Kto ma tylko potrzeby, ale nie potrafi ich zaspokoić, ten umie stawiać tylko wy- 
magania. Do polityki, moralności, wychowania i pracy dołącza się jeszcze sztuka jako ważny obszar życia. Trzeba umieć przeżywać świat nie tylko przez czyn, ale również estetycznie. I na koniec powiedziałbym jeszcze, że trzeba zawsze prowadzić życie ze świadomością, że nie żyje się wiecznie i kiedyś umrzemy oraz że byli ludzie, którzy przed nami odeszli z tego świata i których mimo to możemy nadal włączać do naszego życia.

Nie sądzę, żeby którykolwiek z tych sześciu obszarów był ważniejszy niż inny. Nie ma więc sensu, gdy ktoś mówi: nie mam wprawdzie pracy, ale zamiast tego żyję religijnie. Do pełnej ludzkiej egzystencji i koegzystencji należą one wszystkie, mimo że niekiedy powstają między nimi problemy i konflikty, a nawet spory.

J.B.: I już na zakończenie chciałbym skierować do Pana Profesora bardzo osobiste pytanie: co jest Pana największym szczęściem?

D.B.: Moje największe szczęście? Gdy pracuję, moim największym szczęściem jest odpoczynek. Gdy odpoczywam, moim największym szczęściem jest praca. Ale właściwie największym moim szczęściem - i jestem za to bardzo wdzięczny - jest to, że mogłem poznać bardzo wiele interesujących miejsc, w których dane mi było łączyć odpoczynek i pracę. Jednym z nich jest Warszawa.

M.S./J.B.: Bardzo dziękujemy za rozmowę. 